\title{
Effect of Nano Micronutrients and Nitrogen Foliar Applications on Sugar Beet (Beta vulgaris L.) of Quantity and Quality Traits in Marginal Soils in Egypt
}

\author{
Mohamed D. H. Dewdar ${ }^{1 *}$, Mohamed S. Abbas ${ }^{2}$, Adel S. El-Hassanin ${ }^{2}$ and \\ Hamdy A. Abd El-Aleem ${ }^{3}$ \\ ${ }^{1}$ Agronomy Department, Faculty of Agriculture, Fayoum University, Egypt \\ ${ }^{2}$ Natural Resources Department, Institute of African Research and Studies, \\ Cairo University, Egypt \\ ${ }^{3}$ Fayoum Sugar Company, Etsa, El-Fayoum, Egypt \\ *Corresponding author
}

A B S T R A C T

\section{Keywords}

Nano-fertilizer,

Sugar beet,

Nitrogen,

Microelements

Article Info

Accepted:

26 August 2018

Available Online:

10 September 2018
Agronomic practices may need to be adjusted to maximize yield and quality of sugar beet. Thus agronomic package must be always modified. Nanotechnology is one of the new technologies that entered almost all sides of our lives and were used in agriculture production. Two field experiments will be carried out in the experimental farm of the Etsa region at El- Fayoum governorate, Egypt, during the two successive seasons 2015/16 and 2016/17 to investigate the response of yield and quality of sugar beet cv. Farida to foliar application of nano- microelements mixtures and or urea ( $\mathrm{Zn}, \mathrm{Fe}, \mathrm{B}, \mathrm{Mn}$ and N). Fourteen treatments were studied. The best results were found when sugar beet plants were treated with nano-microelements $200 \mathrm{mg} / \mathrm{L}+$ urea $1 \%$ and ranked as the first favorable treatments for root length and diameter, dry matter per plant as root, top and sugar yields in both seasons, followed by the treatment of nano-microelements $160 \mathrm{mg} / \mathrm{L}+$ urea $\%$ for most traits studied. From the obtained results, it could be concluded that the application of nanomicroelements $200 \mathrm{mg} / \mathrm{L}$ + urea $1 \%$ treatment for producing significantly higher yields with improved quality traits of sugar beet and saving of requirements for plants form micronutrient and nitrogen fertilizer if this fertilizer has been added in the form of nanoparticles.

\section{Introduction}

Sugar is a key item to different nations of the world, since it comes directly after wheat from the vital significance perspective in numerous nations of Europe, Africa, North and South America and Australia, while it possesses the $2^{\text {nd }}$ order after rice in Asian nations.
Agriculture policy of Egypt supports sugar beet cultivators, to increase the cultivated area so increase sugar production and decrease the gap between production and consumption of sugar. So in Egypt, sugar cane was considered to be the main source for sugar industry up to 1981 season and the cultivation of sugar beet was not known economically before 1982 
season. Nowadays, sugar beet became an important crop for sugar in Egypt. Sugar beet contribution to sugar production increased largely from $2.5 \%$ in 1982 to about $48.1 \%$ of the total sugar production in 2012. Sugar beet crop has been an important position in Egyptian crop rotation as a winter crop not only in fertile soils, but also in poor, saline, alkaline and calcareous soils (Gobarahand Mekki, 2005).

Nanotechnology is one of the new technologies that entered almost all sides of our lives and were used in agriculture production. Nowadays nanotechnology has expanded horizons in all fields of science. They are widely used in industrial products, pharmaceuticals, engineering fields, medicine and agriculture (Biswas and $\mathrm{Wu}, 2005$ ).

Nanoparticles are atomic or molecular aggregates with dimension range between 1$100 \mathrm{~nm}$ (Ball, 2002 and Wiesner et al., 2006). Their physiochemical properties are modified because of larger surface to volume ratio in comparison to bulk materials ( $\mathrm{Nel}$ et al., 2006). The chemical and biological activities of most substances increase at nano scale (Mazaherinia et al., 2010).

Nanotechnology can be used in crop production to improve growth and increase yield (Reynolds, 2002). Substituting traditional methods of fertilizer application with nano-fertilizers is a way to release nutrients into the plant gradually and in a controlled way (Naderi and Abedi, 2012).

Hence, nano-fertilizers are either nanomaterials which can supply one or more nutrients to the plants resulting in enhanced growth and yield, or those which facilitate for better performance of conventional fertilizers, without directly providing crops with nutrients. The application of nanoparticles to plants can be beneficial for growth and development due to its ability for greater absorbance and high reactivity (Liu and Lal, 2015).

Nanomaterial could to be applied in designing more soluble and diffusible sources of zinc fertilizer for increased plant productivity. Zinc is an essential micronutrient required for optimum plant growth (Aktas et al., 2006). Zinc plays important roles in various metabolic and physiological processes in the plant, where it activates some enzymes, regulate metabolism of carbohydrates and proteins, which are essential for various processes, critical to development and differentiation of plant cells (Farahat et al., 2007). It is needed in six different classes of enzyme, which include oxidoreductases, transferases, hydrolases, lyases, isomerases and ligases (Auld, 2001).

Utilization of micronutrients like manganese, zinc and iron with balance can enhance and increased productivity of yield sugar beet (Amin et al., 2013, Barłóg et al., 2016 and Rassam et al., 2015). In the meantime, Mekdad and Rady (2016) showed that, adding micronutrient mixtures $(\mathrm{Fe}+\mathrm{Zn}+\mathrm{Mn})$ improved yield and its attributes of sugar beet crop.

The main objective of the study was to throw some light on the effect of nano-fertilizer as foliar spraying micronutrients mixtures; iron $(\mathrm{Fe})$ manganese $(\mathrm{Mn})$, zinc $(\mathrm{Zn})$ and boron $(\mathrm{B})$ beside nitrogen $(\mathrm{N})$ on growth, quality and yield traits of sugar beet.

\section{Materials and Methods}

Two field experiments will be carried out in the experimental farm of the Etsa region at ElFayoum governorate, Egypt during the two successive winter seasons 2015/16 and $2016 / 17$ to investigate the response of root yield and quality of sugar beet (Beta vulgaris 
L.) to foliar application of nanomicroelements mixtures ( $\mathrm{Zn}, \mathrm{Fe}, \mathrm{B}, \mathrm{Mn}$ and Urea). Seeds of sugar beet (Farida) will be obtained from Fayium sugar company, Egypt at two successive winter seasons.

Physical and chemical analyses of the soil were carried out before planting as showed in (Table 1).

The variables investigated in this study will be foliar of nano-microelements applications (T) will be done at 80 and 110 days after sowing (DAS). Fourteen treatments as following:

T1, spraying with tap water

T2, nano-microelements $200 \mathrm{mg} / \mathrm{L}$.

T3, nano-microelements $160 \mathrm{mg} / \mathrm{L}$.

T4, nano-microelements $120 \mathrm{mg} / \mathrm{L}$.

T5, nano-microelements $80 \mathrm{mg} / \mathrm{L}$.

T6, nano-microelements $40 \mathrm{mg} / \mathrm{L}$.

T7, microelements $200 \mathrm{mg} / \mathrm{L}$.

T8, nano-microelements $200 \mathrm{mg} / \mathrm{L} .+$ urea $1 \%$.

T9, nano-microelements $160 \mathrm{mg} / \mathrm{L} . \quad+$ urea1\%.

T10, nano-microelements $120 \mathrm{mg} / \mathrm{L.}+$ urea $1 \%$.

T11, nano-microelements $80 \mathrm{mg} / \mathrm{L} .+$ urea1\%.

T12, nano-microelements $40 \mathrm{mg} / \mathrm{L} .+$ urea $1 \%$.

T13, microelements200 mg / L. + urea $1 \%$.

T14, urea1\%.
Treatments will be arranged in a randomized complete blocks design with four replications. Planting dates will be on the second half of October in the two seasons, the plot area size was $21 \mathrm{~m}^{2}$, and each plot consisted of five ridges of $7 \mathrm{~m}$ in length and $60 \mathrm{~cm}$ in width.

At harvest time, Samples will be analyzed at the laboratory of the Fayoum sugar company. Plants well be separated into tops and roots. The following criteria will be studied; root length $(\mathrm{cm})$, root diameter $(\mathrm{cm})$, root fresh weight per plant $(\mathrm{g})$ and top fresh weight per plant $(\mathrm{g})$.

For determining the dry weight, such parts (tops and roots) will be cut into small pieces, and a representative sample will be taken from each treatment weighed and dried quickly in an oven at $105{ }^{\circ} \mathrm{C}$ till constant weight was reached.

The dry materials obtained were used for estimation of the following characters; root dry weight per plant (g) andtop dry weight per plant (g) traits. The juice of another representative samples from fresh roots will be extracted to determine the following characters; sucrose percentage well be determined by using Sacharometer on a lead acetate extract of fresh macerated root according to the procedure of the Fayoum sugar company of Le-Docte, (1972).

Sucrose percentage, quality percentage, sodium, potassium and alpha amino nitrogen will be determined by using Analyzer - HG in reception laboratory in El-Fayuom Company according to the method of A.O.A.C (1990). Sugar loss to molasses percentage $=0.343(\mathrm{Na}$ $+\mathrm{K})$ - 0.094 (alpha- amino-N) - 0.31, according to Reinefeld et al., (1974). Recoverable sugar percentage (RS \%, corrected sugar \%) was determined by using the following formula Reinefeld et al., (1974) $(\mathrm{RS} \%=\mathrm{Pol} \%-0.029-0.343(\mathrm{Na}+\mathrm{K})-0.094$ 
(alpha-amino-N), where $\mathrm{Pol} \%=$ sucrose $\%$, $\mathrm{K}, \mathrm{Na}$ and amino $-\mathrm{N}$ in Milli equivalent /100 g in beet).

At harvest, plants of all ridges from each subplot will be harvested, cleaned, topped and weighed in plus weight of four plant sample and then it well be converted to estimate; root yield (ton/fed.) and top yield (ton/f.ed.). Apparent or gross sugar yield per feddan $=$ (root yield ton/fed x sucrose \%).

\section{Statistical analysis}

Data will be obtain from each season of the study and it will be statistically analyze to procedures outlined by (Gomez and Gomez, 1984) using MSTAT-C computer program. Treatments mean comparisons will performed using least significant difference (LSD) at 5\% level of probability.

\section{Results and Discussion}

Nanoparticles have great potential to deliver nutrients to specific target sites in living systems. The loading of nutrients on the nanoparticles is usually done by (a) absorption on nanoparticles, (b) attachment on nanoparticles mediated by ligands, (c) encapsulation in nano-particulate polymeric shell, (d) entrapment of polymeric nanoparticles, and (e) synthesis of nano particles composed of the nutrient itself.

Data in Table 2 showed significant positive effect onroot length, root diameter, root fresh weight and top fresh weight traits. Spraying bynano micro-elements and nitrogen foliar applications significantly increase compared with control (spraying with water). The highest value of root length (36.78 and 36.87 $\mathrm{cm})$ for root diameter $(17.16$ and $15.07 \mathrm{~cm})$ as well as root fresh weight (1322 and 1350.44g) in the first and second seasons, respectively and top fresh weight $(1322 \mathrm{~g})$, in the first season only for plants treated with T8 (nanomicroelements $200 \mathrm{mg} / \mathrm{L}$. + urea 1\%) as compared to control (T1) and T14 (urea 1\%). The reminder treatments showed that comparable values for the previous traits.

The nano-fertilizer used in the experiment is a formulated colloidal farming fertilization supplement that facilitates nutrient uptake, transportation and absorption. As shown in Table 2 treatments were significantly increased root length, root diameter, root fresh weight and top fresh weight traits over the control. In addition, the traits were more enhanced when nano-fertilizer was combined with conventional ones, even at a lower application rate. These suggest that nanofertilizer can either provide nutrients for the plant or aid in the transport or absorption of available nutrients resulting in better crop growth. Related study by Liu and Lal (2015), Naderi and Abedi (2012) revealed similar findings on their studies.

Table 3 shows the root dry weight, top dry weight, sodium $\%$ and potassium \%. A significant effect was observed on these parameters when application of conventional fertilizer and its combination with nanofertilizer was done. The data revealed that the treatment of treatments (T8, nanomicroelements $200 \mathrm{mg} / \mathrm{L}$. + urea $1 \%$ and T9, nano-microelements $160 \mathrm{mg} / \mathrm{L}$. + urea1\%.) performed highest values for the above traits.

The data also indicated that the application of (T10, nano-microelements $120 \mathrm{mg} / \mathrm{L} . \quad+$ urea1\%) for root dry weight, top dry weight traits, which in turn scored a significant increments in this parameter as compared to the control (T1).Moreover, it revealed the application of nano fertilizer micronutrients (T2, nano-microelements $200 \mathrm{mg} / \mathrm{L}$ and T3, nano-microelements $160 \mathrm{mg} / \mathrm{L}$ ) rate gave a significant effect on sodium and potassium percentage traits in both seasons. 
Table.1 Physical and chemical analysis of soil of experimental farm of Etsa region

\begin{tabular}{|c|c|c|c|c|c|c|c|}
\hline \multicolumn{2}{|c|}{ Physical analysis } & Chemical analysis & & \multicolumn{2}{|c|}{ Available nutrients } & \multicolumn{2}{|c|}{ Cations (meg/L) } \\
\hline \multirow[t]{2}{*}{ Sand\% } & \multirow[t]{2}{*}{11.5} & $\mathrm{EC}\left(\mathrm{dsm}^{-1}\right)$ & 4.50 & \multirow[t]{2}{*}{ Phosphorus } & \multirow[t]{2}{*}{30.4} & \multirow[t]{2}{*}{$\mathrm{Na}+$} & \multirow[t]{2}{*}{31.7} \\
\hline & & $\mathrm{pH}$ & 7.48 & & & & \\
\hline Silt $\%$ & 12.9 & Organic Matter \% & 0.73 & Potassium & 288 & $\mathrm{Ca}+$ & 8.70 \\
\hline \multirow[t]{2}{*}{ Clay\% } & \multirow[t]{2}{*}{75.6} & \multirow[t]{2}{*}{ Total Nitrogen $\%$} & \multirow[t]{2}{*}{6.8} & Boron & 0.58 & \multirow[t]{2}{*}{$\mathrm{Mg}++$} & \multirow[t]{2}{*}{8.28} \\
\hline & & & & Zinc & 0.74 & & \\
\hline \multirow[t]{2}{*}{ Texture } & \multirow[t]{2}{*}{ Clay } & \multirow[t]{2}{*}{$\mathrm{CaCO}_{3} \%$} & \multirow[t]{2}{*}{11.1} & Manganese & 7.5 & \multirow[t]{2}{*}{$\mathrm{K}+$} & \multirow[t]{2}{*}{0.8} \\
\hline & & & & Iron & 16.4 & & \\
\hline
\end{tabular}

Table.2 Effect of foliar application of nano- micronutrients on root length, root diameter, root fresh weight and top fresh weight traits during two seasons 2015/16 and 2016/17

\begin{tabular}{|c|c|c|c|c|c|c|c|c|}
\hline \multirow[t]{2}{*}{ Treatments } & \multicolumn{2}{|c|}{$\begin{array}{l}\text { Root length } \\
\text { (cm) }\end{array}$} & \multicolumn{2}{|c|}{$\begin{array}{l}\text { Root diameter } \\
(\mathrm{cm})\end{array}$} & \multicolumn{2}{|c|}{$\begin{array}{l}\text { Root fresh weight } \\
\text { (g) }\end{array}$} & \multicolumn{2}{|c|}{$\begin{array}{l}\text { Top fresh } \\
\text { (Weight g) }\end{array}$} \\
\hline & $1^{\text {st }}$ & $2^{\text {nd }}$ & $1^{\text {st }}$ & $2^{\text {nd }}$ & $1^{\text {st }}$ & $2^{\text {nd }}$ & $1^{\text {st }}$ & $2^{\text {nd }}$ \\
\hline T1 & 19.74 & 22.50 & 9.98 & 10.14 & 651 & 742.15 & 651 & 331.25 \\
\hline $\mathbf{T} 2$ & 30.42 & 34.28 & 13.24 & 14.17 & 956 & 1216.05 & 956 & 519.65 \\
\hline T3 & 27.39 & 31.77 & 12.66 & 13.48 & 932 & 1130.32 & 932 & 493.44 \\
\hline T4 & 25.94 & 28.59 & 11.93 & 12.72 & 920 & 1056.00 & 920 & 480.05 \\
\hline T5 & 24.88 & 26.62 & 10.19 & 11.53 & 866 & 970.34 & 866 & 449.07 \\
\hline T6 & 22.82 & 23.74 & 10.00 & 10.72 & 766 & 886.22 & 766 & 402.72 \\
\hline T7 & 25.69 & 26.96 & 12.63 & 12.10 & 936 & 995.49 & 936 & 462.19 \\
\hline T8 & 36.78 & 36.87 & 17.16 & 15.07 & 1322 & 1350.44 & 1322 & 631.67 \\
\hline T9 & 33.74 & 34.12 & 15.66 & 14.90 & 1184 & 1307.64 & 1184 & 568.26 \\
\hline T10 & 30.51 & 33.12 & 14.77 & 14.26 & 1116 & 1249.17 & 1116 & 520.41 \\
\hline T11 & 27.73 & 30.25 & 12.71 & 12.09 & 966 & 1132.18 & 966 & 500.88 \\
\hline T12 & 25.48 & 27.67 & 11.35 & 11.42 & 848 & 1027.62 & 848 & 470.19 \\
\hline T13 & 30.44 & 31.54 & 13.41 & 14.00 & 1050 & 1280.25 & 1050 & 535.53 \\
\hline T14 & 26.36 & 27.76 & 11.36 & 10.40 & 879 & 982.83 & 879 & 432.76 \\
\hline L.S.D. 0.05 & 9.048 & 2.909 & 4.823 & 1.761 & 390.9 & 107.158 & 390.9 & 73.255 \\
\hline
\end{tabular}


Table.3 Effect of foliar application of nano- micronutrients on Root dry weight, top dry weight, Sodium and Potassium traits during two seasons 2015/16 and 2016/17

\begin{tabular}{|c|c|c|c|c|c|c|c|c|}
\hline \multirow[t]{2}{*}{ Treatments } & \multicolumn{2}{|c|}{$\begin{array}{l}\text { Root dry } \\
\text { weight (g) }\end{array}$} & \multicolumn{2}{|c|}{$\begin{array}{c}\text { Top dry } \\
\text { (weight (g) }\end{array}$} & \multicolumn{2}{|c|}{ Sodium \% } & \multicolumn{2}{|c|}{ Potassium \% } \\
\hline & $1^{\text {st }}$ & $2^{\text {nd }}$ & $1_{1}^{\text {st }}$ & $2_{2}^{\text {nd }}$ & $1^{\text {st }}$ & $2_{2}^{\text {nd }}$ & ${ }_{1}^{\text {st }}$ & $2^{\text {nd }}$ \\
\hline T1 & 103.80 & 117.21 & 46.9 & 52.36 & 2.497 & 2.73 & 5.947 & 5.84 \\
\hline T2 & 152.5 & 198.02 & 68.8 & 86.97 & 1.760 & 1.60 & 4.030 & 3.97 \\
\hline T3 & 148.6 & 177.39 & 67.0 & 80.71 & 1.845 & 1.61 & 4.235 & 4.10 \\
\hline T4 & 139.5 & 167.61 & 66.9 & 73.84 & 2.070 & 1.98 & 4.453 & 4.22 \\
\hline T5 & 134.0 & 155.44 & 62.0 & 68.50 & 2.167 & 2.10 & 4.573 & 4.43 \\
\hline T6 & 122.2 & 139.96 & 56.4 & 62.83 & 2.240 & 2.77 & 4.805 & 4.80 \\
\hline T7 & 153.1 & 151.80 & 66.7 & 70.21 & 2.087 & 2.00 & 4.915 & 4.16 \\
\hline T8 & 211.7 & 210.88 & 95.1 & 98.48 & 1.512 & 1.16 & 4.463 & 4.35 \\
\hline T9 & 192.1 & 186.71 & 87.1 & 92.33 & 1.837 & 1.45 & 4.888 & 4.53 \\
\hline T10 & 179.6 & 178.42 & 80.7 & 84.39 & 2.085 & 1.82 & 5.363 & 5.01 \\
\hline T11 & 152.5 & 172.89 & 67.8 & 75.46 & 2.212 & 2.18 & 5.537 & 5.10 \\
\hline T12 & 135.4 & 164.15 & 59.2 & 73.35 & 2.387 & 2.27 & 5.638 & 5.22 \\
\hline T13 & 171.8 & 192.12 & 77.3 & 85.41 & 2.105 & 2.24 & 5.583 & 4.80 \\
\hline T14 & 140.4 & 161.11 & 67.0 & 70.20 & 2.212 & 2.85 & 5.463 & 5.82 \\
\hline L.S.D. 0.05 & 61.71 & 19.929 & 27.29 & 9.237 & 0.6373 & 0.486 & 0.5852 & 0.823 \\
\hline
\end{tabular}

Table.4 Effect of foliar application of nano-micronutrients on alpha-amino nitrogen sucrose, quality and sugar loss to molasses traits during two seasons 2015/16 and 2016/17

\begin{tabular}{|c|c|c|c|c|c|c|c|c|}
\hline \multirow[t]{2}{*}{ Treatments } & \multicolumn{2}{|c|}{$\begin{array}{l}\text { Alpha-amino } \\
\text { nitrogen }\end{array}$} & \multicolumn{2}{|c|}{ Sucrose \% } & \multicolumn{2}{|c|}{ Quality \% } & \multicolumn{2}{|c|}{$\begin{array}{l}\text { Sugar loss to } \\
\text { Molasses \% }\end{array}$} \\
\hline & $1^{\text {st }}$ & $2_{2}^{\text {nd }}$ & $1^{\text {st }}$ & $2^{\text {nd }}$ & $1^{\text {st }}$ & $2^{\text {nd }}$ & $1^{\text {st }}$ & $2_{2}^{\text {nd }}$ \\
\hline T1 & 0.71 & 0.67 & 14.39 & 16.22 & 77.69 & 80.15 & 2.54 & 2.52 \\
\hline T2 & 0.13 & 0.12 & 19.09 & 20.29 & 88.11 & 89.01 & 1.55 & 1.74 \\
\hline T3 & 0.22 & 0.20 & 18.80 & 19.42 & 87.25 & 87.73 & 1.71 & 1.74 \\
\hline T4 & 0.25 & 0.27 & 17.38 & 18.56 & 85.38 & 87.02 & 1.78 & 1.90 \\
\hline T5 & 0.31 & 0.38 & 17.12 & 18.30 & 84.13 & 86.56 & 1.88 & 1.97 \\
\hline T6 & 0.42 & 0.50 & 16.80 & 17.86 & 83.79 & 83.76 & 2.23 & 2.14 \\
\hline T7 & 0.24 & 0.23 & 17.19 & 18.55 & 85.40 & 86.98 & 1.82 & 1.89 \\
\hline T8 & 1.46 & 1.30 & 17.44 & 19.00 & 86.33 & 88.40 & 1.52 & 1.57 \\
\hline T9 & 1.61 & 1.42 & 17.11 & 18.79 & 85.33 & 86.24 & 1.61 & 1.82 \\
\hline T10 & 1.68 & 1.53 & 16.86 & 18.20 & 82.20 & 85.49 & 1.92 & 2.06 \\
\hline T11 & 1.73 & 1.62 & 15.99 & 17.65 & 81.21 & 83.85 & 2.03 & 2.16 \\
\hline T12 & 1.71 & 1.74 & 15.59 & 17.42 & 80.05 & 82.93 & 2.43 & 2.170 \\
\hline T13 & 1.61 & 1.65 & 16.24 & 17.00 & 81.56 & 84.52 & 1.95 & 2.172 \\
\hline T14 & 1.73 & 1.82 & 15.84 & 16.11 & 80.67 & 80.70 & 2.70 & 2.157 \\
\hline L.S.D. 0.05 & 0.272 & 0.317 & 1.255 & 1.202 & 1.814 & 2.571 & 0.393 & 0.2072 \\
\hline
\end{tabular}


Table.5 Effect of foliar application of nano-micronutrients on recoverable sugar, sugar yield, root yield and top yield traits during two seasons 2015/16 and 2016/17

\begin{tabular}{|c|c|c|c|c|c|c|c|c|}
\hline \multirow[t]{2}{*}{ Treatments } & \multicolumn{2}{|c|}{$\begin{array}{l}\text { Recoverable } \\
\text { sugar \% }\end{array}$} & \multicolumn{2}{|c|}{$\begin{array}{c}\text { Sugar yield } \\
\text { (ton/fed.) }\end{array}$} & \multicolumn{2}{|c|}{$\begin{array}{l}\text { Root yield } \\
\text { ton / fed.)) }\end{array}$} & \multicolumn{2}{|c|}{$\begin{array}{l}\text { Top yield } \\
\text { (ton /fed.) }\end{array}$} \\
\hline & $1^{\text {st }}$ & $2_{2}^{\text {nd }}$ & $1^{\text {st }}$ & $2_{2}^{\text {nd }}$ & $1^{\text {st }}$ & $2_{2}^{\text {nd }}$ & $1^{\text {st }}$ & $2_{2}^{\text {nd }}$ \\
\hline T1 & 11.40 & 13.19 & 2.34 & 3.01 & 16.28 & 18.55 & 7.48 & 8.49 \\
\hline $\mathrm{T} 2$ & 17.09 & 18.27 & 4.80 & 6.65 & 25.81 & 32.90 & 10.99 & 13.32 \\
\hline T3 & 16.63 & 17.35 & 4.66 & 5.47 & 24.80 & 28.25 & 10.71 & 12.65 \\
\hline T4 & 15.09 & 16.39 & 4.19 & 5.08 & 24.11 & 27.40 & 10.46 & 12.30 \\
\hline T5 & 14.77 & 16.01 & 4.05 & 4.44 & 23.70 & 24.25 & 9.91 & 11.49 \\
\hline T6 & 14.25 & 15.19 & 3.46 & 3.93 & 20.65 & 22.15 & 8.76 & 10.32 \\
\hline $\mathrm{T} 7$ & 14.91 & 16.35 & 4.26 & 4.98 & 24.83 & 26.87 & 10.81 & 11.85 \\
\hline T8 & 15.22 & 17.19 & 5.62 & 7.03 & 33.50 & 36.75 & 15.20 & 16.19 \\
\hline T9 & 14.58 & 16.16 & 5.83 & 6.24 & 29.60 & 32.67 & 13.74 & 14.57 \\
\hline T10 & 14.12 & 15.82 & 4.68 & 5.68 & 27.77 & 31.22 & 12.75 & 13.34 \\
\hline T11 & 13.14 & 14.98 & 3.85 & 4.99 & 24.12 & 28.30 & 11.11 & 12.82 \\
\hline T12 & 12.72 & 14.45 & 3.29 & 4.47 & 21.17 & 25.67 & 9.44 & 12.05 \\
\hline T13 & 13.43 & 15.31 & 4.40 & 5.74 & 27.25 & 32.00 & 12.37 & 13.73 \\
\hline T14 & 12.96 & 12.91 & 3.47 & 3.95 & 21.95 & 24.55 & 10.73 & 11.09 \\
\hline L.S.D. 0.05 & 1.262 & 1.438 & 1.607 & 0.594 & 9.841 & 2.714 & 1.82 & 1.92 \\
\hline
\end{tabular}

The rest treatments showed that the comparable values for the same traits.

In this respect, Aktas et al., 2006, cited that nano-material could to be applied in designing more soluble and diffusible sources of zinc fertilizer for increased plant productivity. They found that zinc and boron are an essential micronutrient required for optimum plant growth and quality of sugar beet.

Data in Table 4 illustrated that the effect of applications of nano micronutrients and or urea were significant on alpha-amino nitrogen, sucrose $\%$, quality $\%$ and sugar loss to molasses \%. T2 and T3 have the largest values followed by the two treatments $\mathrm{T} 8$ and T9 for sucrose percentage and quality traits in both seasons as compared to the control (T1).The obtained values were 19.09, 20.29, 18.60 and $19.42 \%$ for sucrose \% for T2 and T3 treatments in both seasons, 17.44, 19.00,
17.11 and $18.79 \%$ for $\mathrm{T} 8$ and $\mathrm{T} 9$ for the same trait in the two seasons, respectively.

In contrary, data revealed the lowest values exhibited for the same treatments for alpha amino nitrogen and sugar loss to molasses traits compared with control. Whereas, the values were 0.13 and 0.12 for amino alpha nitrogen in T2 in both seasons. While, values of T3 were 0.22 and 0.20 for the same trait. Further, the beneficial effect of the reminder treatments resulted in improvements of the previously four traits.

In this concern, Farahat et al., (2007) reported that the nano micronutrients form are an important micronutrient needed in small amounts by crop plants. Its important roles in various metabolic and physiological processes in the plant, where it activates some enzymes, regulate metabolism of carbohydrates and proteins, which are essential for various processes, critical to development and 
differentiation of plant cells. In adding, Auld, (2001), found that the six different classes of enzyme, which include oxidoreductases, transferases, hydrolases, lyases, isomerases and ligases.

The data in Table 5 demonstrate that treating sugar beet plants with nano micronutrients (T8 and T9) exerted higher values than the other treatments for recoverable sugar percentage, sugar yield, root yield and top yield traits in the two seasons compared with the control (T1).

The rest treatments recorded beneficial effect and comparable values for aforementioned traits. These pronounced increments may be due to the fact that, nano-fertilizer may have a synergistic effect on the conventional fertilizer for better nutrient absorption by plant cells resulting to optimal growth.

Further, the ability of a sink to mobilize photosynthates toward itself is often known as sink strength, which depends on two factors namely, sink size and sink activity. Sink size is the total biomass of the sink tissue while sink activity is the rate of uptake of photosynthates per unit biomass of sink tissue (Taiz and Zaiger, 2006).

As mentioned earlier, nano-fertilizer may have affected these processes through its nutrient transportation capability in terms of penetration and movement of a wide range of nutrients, from roots uptake to foliage penetration and movements within the plant. A number of studies proved the significance of nano-fertilizers. It is clear from the above that these processes contribute to the formation of carbohydrates, which is reflected in the increase of the sugar yields.

Application of nanotechnology in agriculture is still in its budding stage. However, it has the potential to revolutionize agricultural systems particularly where the issues on fertilizer applications are concerned.

Nano-fertilizer application promoted the growth, development and antioxidant activity in sugar beet plants and has the potential to improve crop production and plant nutrition. Moreover, nano-fertilezers have great impact on the soil, can reduce the toxicity of the soil and decrease the frequency of fertilizer application.

The outcome of this research would be beneficial for other studies involving the application of nanotechnology in the field of agriculture. In the future, this study needs to complete economically the cost of adding fertilizer to nanotechnology, whether it is suitable for farmers or not.

\section{References}

A.O.A.C. (1990). Official Methods of Analysis. 15th Ed. Association of Official Analytical Chemists, Washington, USA.

Aktas, H., Abak, K., Ozturk, L. and Cakmak, S. (2006): The effect of Zinc on growth and shoot concentrations of sodium and potassium in pepper plants under salinity stress. Turk J. Agric. For., 30: 407-412.

Amin G. A., Badr. E.A., and Afifi, M.H.M. (2013). Root yield and quality of sugar beet (Beta vulgaris L.) in response to biofertilizer and foliar application with micronutrients. World Appl. Sci. J., 27 (11): 1385-1389.

Auld, D.S. (2001): Zinc coordination sphere in biochemical zinc sites. Biometals, 14: 271-313.

Ball P, (2002). Natural strategies for the molecular engineer., Nanotech. 13:1528.

Barłóg, P., Nowacka, A. and Błaszyk, R. (2016). Effect of zinc band application 
on sugar beet yield, quality and nutrient uptake. Plant Soil Environ. 62(1), 30 35.

Biswas, P. and Wu, C.Y. (2005). Critical review nanoparticles and the environment. J. Air Waste Manage. Assoc., 55: 708-746.

Farahat, M.M., Ibrahim, S., Taha, L.S. and ElQuesni, F.E.M. (2007). Response of vegetative growth and some chemical constituents of Cupressus sempervirens L. to foliar application of ascorbic acid and zinc at Nubaria. World J. Agric. Sci., 3(4): 496-502.

Gobarah, ME, Mekki BB. (2005). J. App. Sci. Res., 1 (5): 373-379.

Gomez KA, Gomez AA. (1984). Statistical Procedures for Agricultural Research, Wiley and sons, New York.

Le-Docte, A., (1972). Commercial determination of sugar in beet root using Sackr Le-Docte Process. Int. Sugar J., 29: 448-492.

Liu, R. and Lal, R. (2015). Potentials of engineered nanoparticles as fertilizers for increasing agronomic productions. A review. Sci. of the Total Envir., 514: 131-139.

Mazaherinia, S., Astaraei, A.R., Fotovat, A. and Monshi, A. (2010). Nano iron oxide particles efficiency on $\mathrm{Fe}, \mathrm{Mn}, \mathrm{Zn}$ and $\mathrm{Cu}$ concentrations in wheat plant. World Applied Sciences Journal, 7(1): 36-40.

Mekdad, A.A. and Rady, M.M. (2016). Response of Beta vulgaris L. to nitrogen and micronutrients in dry environment. Plant Soil Environ. 62 (1): 23-29.

Naderi, M.R. and Abedi, A. (2012). Application of nanotechnology in agriculture and refinement of environmental pollutants. Journal of Nanotechnology, 11(1): 18-26

Nel, A., Xia, T., Madler, L. and Li, N. (2006). Toxic potential of materials at the nanolevel. Science, 311: 622-627.

Rassam, G., Dashti, M., Dadkhah, A. Yazdi, A. K. (2015). Root Yield and Quality of sugar beet in relation to foliar application of micronutrients. Annals of West Univ., of Timişoara, ser. Biology, Vol XVIII (2): 87-94.

Reinfeld E Emmerich G Baumgarten C Winner and $U$ Beiss. 1974. Zurvoraussage des Melassezzuckersaus Rubenanalysen Zucker, 27, 215.C.F.The sugar beet crop, Edit.by Cooke DA, R K Scott. First Edit. 1993, Chapman \&Hall, World Crop Series, London, U.K.

Reynolds, G.H. (2002). Forward to the future nanotechnology and regulatory policy. Pacific Research Institute, 24: 1-23.

Taiz, L and Zeiger, E. (2006). Plant Physiology. 4th Edition. Sinauer Associates, Inc. Sunderland, Massachusetts, USA.

Wiesner, M.R., Lowry, G.V., Alvarez, P., Dionysiou, D. and Biswas, P. (2006). Assessing the risks of manufactured nano-materials. Environ. Sci. Technol., 40(14): 4336-4345.

\section{How to cite this article:}

Mohamed, D.H. Dewdar, Mohamed S. Abbas, Adel S. El-Hassanin and Hamdy A. Abd ElAleem. 2018. Effect of Nano Micronutrients and Nitrogen Foliar Applications on Sugar Beet (Beta vulgaris L.) of Quantity and Quality Traits in Marginal Soils in Egypt. Int.J.Curr.Microbiol.App.Sci. 7(09): 4490-4498. doi: https://doi.org/10.20546/ijcmas.2018.708.475 